\title{
Induction and overcoming of dormancy of grapevine buds in response to thermal variations in the winter period
}

\author{
Rafael Anzanello ${ }^{* *}$ (D) Cláudia Martellet Fogaça ${ }^{1}$ (D) Gabriele Becker Delwing Sartori ${ }^{1}$ (D)
}

'Departamento de Diagnóstico e Pesquisa Agropecuária, Secretaria da Agricultura, Pecuária e Desenvolvimento Rural, 95330-000, Veranópolis, RS, Brasil. E-mail: rafael-anzanello@agricultura.rs.gov.br. "Corresponding author.

\begin{abstract}
This study quantified the chilling requirements for the induction and overcoming of endodormancy (chilling-controlled physiological dormancy) of grapevines buds. Cuttings of the cultivars Chardonnay, Merlot and Cabernet Sauvignon were collected in vineyards in Veranópolis-RS in the winter period of 2019 and 2020. The cuttings were kept at a constant temperature of $7.2{ }^{\circ} \mathrm{C}$ or daily cycles of $7.2 / 18$ ${ }^{\circ} \mathrm{C}$ for $6 / 18 \mathrm{~h}, 12 / 12 \mathrm{~h}$ or $18 / 6 \mathrm{~h}$, up to 600 chilling hours $(\mathrm{CH})$. Every $50 \mathrm{CH}$, part of the cuttings from each treatment was transferred to a temperature of $25^{\circ} \mathrm{C}$ for daily assessment of the budburst in the green tip stage. The cultivars had different chilling requirements for inducing and overcoming endodormancy, reaching a total of $150 \mathrm{CH}$ for 'Chardonnay', $300 \mathrm{CH}$ for 'Merlot' and $400 \mathrm{CH}$ for 'Cabernet Sauvignon'. Of these, $50 \mathrm{CH}$ were required to induce endodormancy in cultivars Chardonnay and Merlot and $100 \mathrm{CH}$ for cultivar Cabernet Sauvignon. Dormancy evolution did not differ between cultivars in response to thermal regimes, with a temperature of $18{ }^{\circ} \mathrm{C}$ inert to the accumulation of CH. Precocity and uniformity of budburst were higher after chilling requirements were met during endodormancy for each genotype. Key words: chilling hours, endodormancy, budburst, Vitis vinifera.
\end{abstract}

Indução e superação da dormência de gemas de videiras em resposta a variações térmicas no período hibernal

RESUMO: Este estudo visou quantificar as necessidades de frio para a indução e superação da endodormência (dormência fisiológica controlada por frio) de gemas de videiras. Estacas de das cultivares Chardonnay, Merlot e Cabernet Sauvignon foram coletadas em vinhedos em Veranópolis-RS, no periodo hibernal de 2019 e 2020. As estacas foram submetidas a temperatura de 7,2 ${ }^{\circ} \mathrm{C}$ constante ou a ciclos diários de $7,2 / 18{ }^{\circ} \mathrm{C}$ por $6 / 18 \mathrm{~h}, 12 / 12 \mathrm{~h}$ ou $18 / 6 \mathrm{~h}$, até 600 horas de frio (HF). A cada $50 \mathrm{HF}$, parte das estacas de cada tratamento foi transferida para a temperatura de $25^{\circ} \mathrm{C}$, para avaliação diária da brotação das gemas, em estádio de ponta verde. As cultivares tiveram necessidades distintas de frio para indução e superação da endodormência, atingindo um total de $150 \mathrm{HF}$ para 'Chardonnay', $300 \mathrm{HF}$ para 'Merlot' $\mathrm{e} 400$ HF para 'Cabernet Sauvignon'. Destes totais, 50 HF foram necessárias para indução da endodormência nas cultivares Chardonnay e Merlot e $100 \mathrm{HF}$ na cultivar Cabernet Sauvignon. A evolução da dormência não diferiu entre cultivares em resposta aos regimes térmicos, sendo a temperatura de $18{ }^{\circ} \mathrm{C}$ inerte ao acúmulo de HF. A precocidade e uniformidade de brotação das gemas foram maiores após suprido o frio na dormência para cada genótipo.

Palavras-chave: horas de frio, endodormência, brotação, Vitis vinifera.

\section{INTRODUCTION}

In southern Brazil, plants must be exposed to a period of low temperatures during autumn and winter for the grapevine to start a new vegetative cycle in spring, thus overcoming endodormancy (chilling-controlled dormancy) (ANZANELLO et al., 2018). Failure to meet chilling requirements during endodormancy can cause insufficient and/or uneven budburst of the plants, compromising the production of fruits (MARAFON et al., 2011).

The amount of chilling required to overcome endodormancy varies according to species and fruit cultivars (LUEDELING \& BROWN, 2011). In general, the accumulation of chilling hours $(\mathrm{CH})$ is the sum of hours equal to or below $7.2{ }^{\circ} \mathrm{C}$, a generic temperature for fruits growing in temperate climate (WEINBERGER, 1950). Other models, such as the Utah and North Carolina models, have been used to estimate the amount of chilling required to overcome endodormancy and consequent budburst induction (RICHARDSON et al., 1974; SHALTOUT \& UNRATH, 1983), which evaluate the quality of the accumulated chilling during autumn and winter, giving weight to the chilling actions at each temperature. 
Large thermal fluctuations are common in southern Brazil during the winter period. However, the dormancy models usually used have been adjusted to North American climatic conditions (RICHARDSON et al., 1974; SHALTOUT \& UNRATH, 1983), which are marked by relatively constant and regular autumns and winters. Moreover, these models were developed for peach and apple crops. This makes them unreliable and largely inaccurate when applied to the grapeproducing regions of southern Brazil (FELIPPETO et al., 2013). Thus, the role of heat and chilling in the evolution and overcoming of dormancy should be better studied in order to adjust and develop betteradapted models for the prediction of the budburst potential of the grapevine culture.

Characterizing dormancy has gained greater relevance in the face of current and future global climate change. These prospects already show significant reduction in the availability of winter chilling in regions that traditionally produce temperate fruits in Brazil (CARDOSO et al., 2012). This climatic change can directly impact the state of endodormancy and the budburst capacity of grapevine and other temperate climate fruit species. Therefore, models of characterization of biological responses (e.g., dormant state) adjusted for unstable temperatures in autumns and winters are important for forecasting crop scenarios, thus minimizing the losses caused by the increase in temperature. These accurate models can be used in decision making on the management practices of grapevine budburst.

This study determined the chilling requirements for the induction and overcoming of the endodormancy of grapevine buds of the Chardonnay, Merlot and Cabernet Sauvignon cultivars under varying thermal conditions.

\section{MATERIALS AND METHODS}

Grapevines cuttings of the Chardonnay, Merlot and Cabernet Sauvignon cultivars were collected from commercial vineyards in the municipality of Veranópolis-RS, in the Serra Gaúcha, in the winters of 2019 and 2020, with zero $\mathrm{CH}$ in the field. The cuttings were collected from the middle of the branches. They measured $40-60 \mathrm{~cm}$ in length, approximately $1 \mathrm{~cm}$ in diameter, had 5 buds per cutting, and were without leaves. Bud maturity (wellclosed buds), the health, and vigor of the cuttings were considered when selecting them for sampling, giving priority to those with intermediate growth.

After the branches were collected, they were wrapped in newspaper bundles, moistened, placed in plastic bags and transported to the Department of Diagnosis and Agricultural Research (Departamento de Diagnóstico e Pesquisa Agropecuária - DDPA), of the Secretariat of Agriculture, Livestock and Rural Development of the State of RS (Secretaria da Agricultura Pecuária e Desenvolvimento Rural do Estado do RS - SEAPDR), in Veranópolis-RS. Thereafter, the branches were evaluated for bud dormancy under controlled conditions. The cuttings were cleaned according to the methodology proposed by ANZANELLO et al. (2014).

After disinfestation, the cuttings were processed by cutting one end in a bevel, approximately $1 \mathrm{~cm}$ above the bud, and the other one approximately $7 \mathrm{~cm}$ below the first cut, forming single-node cuttings (cuttings with a single bud). The cuttings were planted in pots with moistened phenolic foam and were maintained at a constant temperature of $7.2^{\circ} \mathrm{C}$ in 2019 and were kept at a constant temperature of $7.2{ }^{\circ} \mathrm{C}$ or subjected to daily cycles from $7.2 / 18{ }^{\circ} \mathrm{C}$ for $6 / 18 \mathrm{~h}, 12 / 12 \mathrm{~h}$ or $18 / 6 \mathrm{~h}$ ) in 2020 , until they reached $600 \mathrm{CH}$. At every $50 \mathrm{CH}$, part of the cuttings from each treatment was transferred to a temperature of $25{ }^{\circ} \mathrm{C}$ and a photoperiod of $12 \mathrm{~h}$ of light, for the induction and association of the budburst in the green tip stage. A randomized block design was used to control the effect of variation in air circulation inside the incubator chambers. For each combination of temperature and exposure time, three repetitions were available ( 3 pots with 10 cuttings).

The cuttings in the incubator chambers were irrigated every $48-72 \mathrm{~h}$, replacing the water to saturate the phenolic foam. The preventive control of diseases in the cuttings was carried out using chemical pesticides containing pyrimethanil and tebuconazole (systemic) and iprodione and captan (contact), sprayed at a dosage of 1.5 to $2.0 \mathrm{ml} \mathrm{L}$. The pesticides were applied every 14 to 21 days, with both, contact and systemic products.

The budburst was assessed every $2-3$ days until the 35th day. The data on the final budburst rate (percentage of budburst), precocity (number of days until the budburst of the first bud) and uniformity (number of days between the first and last sprouted bud) were subjected to analysis of variance (ANOVA). The features with significant differences by the $\mathrm{F}$ test had their means compared by Tukey's test at $5 \%$ probability.

\section{RESULTS AND DISCUSSION}

The experimental conditions were successful in inducing and overcoming endodormancy. 
An initial reduction in budburst (dormancy induction), followed by an increase in budburst to high levels (dormancy overcoming), for all cultivars and thermal conditions was observed (Figures $1 \mathrm{~A}$ and 2). The cultivars had distinct chilling requirements for induction and overcoming endodormancy, reaching a total of $150 \mathrm{CH}$ in 'Chardonnay' (Figures $1 \mathrm{~A}$ and 2A), $300 \mathrm{CH}$ in 'Merlot' (Figures 1A and 2B) and $400 \mathrm{CH}$ in 'Cabernet Sauvignon' (Figures 1A and $2 \mathrm{C}$ ). Of these, $50 \mathrm{CH}$ were required to induce endodormancy in 'Chardonnay' and 'Merlot' and 100 $\mathrm{CH}$ were required in 'Cabernet Sauvignon'. Total chilling requirements are similar to those obtained by ANZANELLO et al. (2018) for 'Chardonnay' (138 $\mathrm{CH})$, 'Merlot' (298 CH) and 'Cabernet Sauvignon' $(392 \mathrm{CH})$. The difference in the chilling requirements among the grapevine genotypes is compatible with the phenology of the cultivars observed in the field
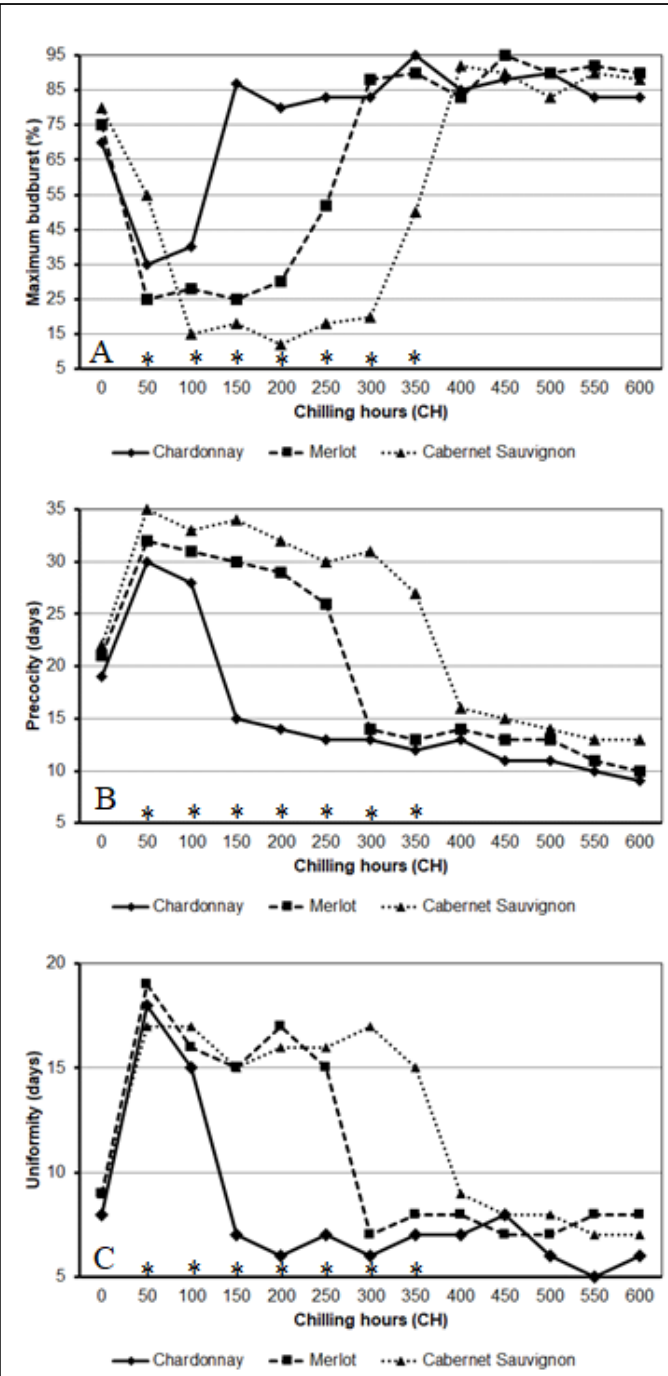

Figure 1 - Maximum budburst (A), precocity (B) and budburst uniformity (C) of 'Chardonnay', 'Merlot' and 'Cabernet Sauvignon' kept at a constant temperature of $7.2{ }^{\circ} \mathrm{C}$ during the dormancy period. Significant differences within each chilling hour by the Tukey's test $(\mathrm{P}<0.05)$ are marked with an $\left(^{*}\right)$

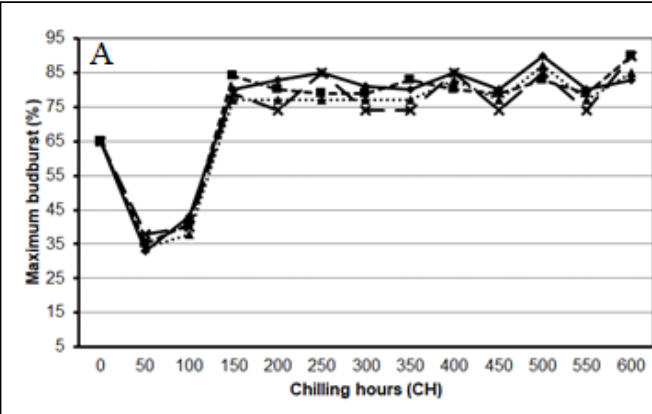

$\rightarrow 7.2^{\circ} \mathrm{C}-\mathbf{- 1}-1816 \mathrm{~h}\left(7.2 / 18^{\circ} \mathrm{C}\right) \cdots \mathbf{*} \cdot 12 / 12 \mathrm{~h}\left(7.2 / 18^{\circ} \mathrm{C}\right) \rightarrow 6 / 18 \mathrm{~h}\left(7.2 / 18^{\circ} \mathrm{C}\right)$

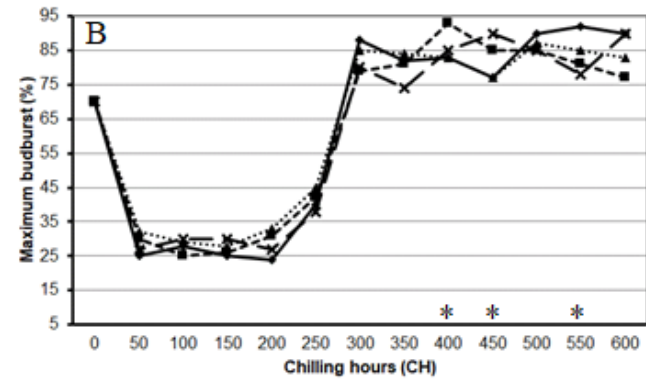

$\rightarrow 7.2^{\circ} \mathrm{C}-\mathbf{m}-18.6 \mathrm{~h}\left(7.2 / 18^{\circ} \mathrm{C}\right) \cdots \cdot \cdots 12 / 12 \mathrm{~h}\left(7.2 / 18^{\circ} \mathrm{C}\right) \rightarrow 6 / 18 \mathrm{~h}\left(7.2 / 18^{\circ} \mathrm{C}\right)$

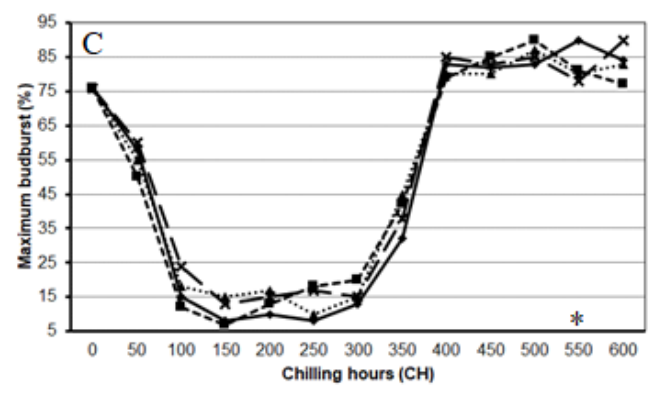

$\rightarrow-7.2^{\circ} \mathrm{C}=-18 / 6 \mathrm{~h}\left(7.2 / 18^{\circ} \mathrm{C}\right) \cdots \cdot \cdots 12 / 12 \mathrm{~h}\left(7.2 / 18^{\circ} \mathrm{C}\right) \rightarrow 6 / 18 \mathrm{~h}\left(7.2 / 18^{\circ} \mathrm{C}\right)$

Figure 2 - Maximum budburst of 'Chardonnay' (A), 'Merlot' (B) and 'Cabernet Sauvignon' (C) kept at a constant temperature of $7.2^{\circ} \mathrm{C}$ and alternating temperatures of $7.2 / 18^{\circ} \mathrm{C}$ during the dormancy period. Significant differences in maximum budburst within each chilling hour by the Tukey's test $(\mathrm{P}<0.05)$ are marked with an $\left(^{*}\right)$.

Ciência Rural, v.51, n.11, 2021. 
- 'Chardonnay' budburst occurred on 08/23, 'Merlot' on 09/13, and 'Cabernet Sauvignon' on 09/18 in Serra Gaúcha region (MANDELLI et al., 2003). This showed that the lower the requirement for chilling during dormancy, the greater the precocity of the cultivar.

The values of initial budburst (zero point, Figures 1A, 2A, 2B and 2C) were around $65 \%$ in 'Chardonnay' and $70 \%-80 \%$ in 'Merlot' and 'Cabernet Sauvignon'. It is not clear that the buds enter dormancy only with artificial cooling, especially for 'Chardonnay'. The low percentage of initial budburst in this cultivar may indicate that the bud dormancy was already being induced in the field. COOKE et al. (2012) affirmed that dormancy can be introduced by changes in the photoperiod, as well as effects of biotic and abiotic stresses in the field, which prevent the buds from growing (for example: pathogenic or water stress), and does not depend exclusively on temperature. The Chardonnay cultivar showed higher rates of downy mildew (caused by Plasmopara viticola) in the 2019 and 2020 crop seasons and; consequently, early leaf loss, compared to 'Merlot' and 'Cabernet Sauvignon', thus inducing dormancy even before the occurrence of the first chilling. The earlier 'Chardonnay' cycle also contributed to an earlier bud dormancy compared to 'Merlot' and 'Cabernet Sauvignon', given the different phenological cycle among cultivars (MANDELLI et al., 2003; FELIPPETO et al., 2013).

The Chardonnay cultivar showed slight dormancy, with $35 \%-45 \%$ budburst in the period of maximum endodormancy, and 'Merlot' and 'Cabernet Sauvignon' showed deeper dormancy, achieving $25 \%-35 \%$ budburst in 'Merlot' and 5\%-20\% budburst in 'Cabernet Sauvignon' in the same stage (Figures 1A, 2A, 2B and 2C). For MELKE (2015), the dormancy of temperate fruit can be divided into three levels: slight, intermediate and deep. For cultivars with "slight" dormancy such as 'Chardonnay', bud growth is partially interrupted during endodormancy. Cultivars with an "intermediate to deep" level of dormancy such as 'Merlot' and 'Cabernet Sauvignon', are characterized by a large, or almost total, interruption in bud growth. ANZANELLO et al. (2018), when working with the same cultivars under similar temperature conditions, obtained dormancy levels identical to the present study.

The evolution of dormancy showed that there is a direct relationship between the level of dormancy and the total chilling requirement of the cultivar. The greater the depth of dormancy, the greater the chilling requirements of the genotypes. For example, 'Merlot' and 'Cabernet Sauvignon', which had deeper dormancy, required longer $\mathrm{CH}$ to overcome the endodormancy stage and return to a maximum budburst. Similar relationships were observed in apple trees, when total $\mathrm{CH}$ were associated with bud dormancy depth (ANZANELLO et al., 2014).

The constant $\left(7.2^{\circ} \mathrm{C}\right)$ or alternating $(6 / 18$ $\mathrm{h}, 18 / 6 \mathrm{~h}$ and $12 / 12 \mathrm{~h}$ to $7.2 / 18^{\circ} \mathrm{C}$ ) thermal conditions did not produce varying responses to chilling in each cultivar - suggesting that the response of each genotype within the analyzed thermal range depends only on chilling availability $\left(7.2^{\circ} \mathrm{C}\right)$ and using a higher temperature $\left(18^{\circ} \mathrm{C}\right)$ had no effect (Figure 2). Similar results were observed by RICHARDSON et al. (1974) in peach buds, by SHALTOUT \& UNRATH (1983) and ANZANELLO et al. (2014) in apple trees, and by ANZANELLO et al. (2018) in grapevines, with $3{ }^{\circ} \mathrm{C}$ being able to meet chilling requirements, and a moderate temperature of $15{ }^{\circ} \mathrm{C}$ showing no effect. EREZ \& FISHMAN (1990) also showed that moderate temperatures $\left(15^{\circ} \mathrm{C}\right)$ in a 6 ${ }^{\circ} \mathrm{C}$ chilling treatment were not harmful and helped to overcome dormancy in peach buds. The importance of alternating heat $\left(15-20^{\circ} \mathrm{C}\right)$ with chilling $\left(3-6^{\circ} \mathrm{C}\right)$ in overcoming dormancy has also been indicated in other studies with apricot, apple and peach (GUERRIERO et al., 1985; NAOR et al., 2003; SUGIURA et al., 2010). However, the present study did not show a beneficial effect of cyclical temperatures in grapevine cultivars, showing a similar effect at the constant $7.2{ }^{\circ} \mathrm{C}$ chilling temperature and $7.2{ }^{\circ} \mathrm{C}$ chilling temperature alternating with $18^{\circ} \mathrm{C}$ heat (Figures $2 \mathrm{~A}$, $2 \mathrm{~B}$ and $2 \mathrm{C}$ ).

In most fruit trees, high temperatures $(\geq 20$ ${ }^{\circ} \mathrm{C}$ ) interspersed with chilling reduce or even reverse $\mathrm{CH}$ accumulation. In peach and apple trees, part of the chilling accumulation can be canceled out by high temperatures in winter (EREZ et al., 1979). It has not yet been established whether this model is also relevant for grapevine dormancy (FERGUSON et al., 2011). The relevance of this phenomenon for grapevine buds, commonly referred to as "chilling nullification or reversal", is unknown (DOKOOZLIAN, 1999). In the present study, chilling was applied continuously or with interruptions, at a temperature of $18{ }^{\circ} \mathrm{C}$. Further studies are needed to better understand how dormancy in grapevines evolves with exposure to warmer temperatures in winter.

Budburst precocity and uniformity followed a similar response pattern with the evolution of endodormancy, not being affected by the thermal regime or cultivar (Figure 3 ). In the case of precocity, during the period of maximum endodormancy, the 

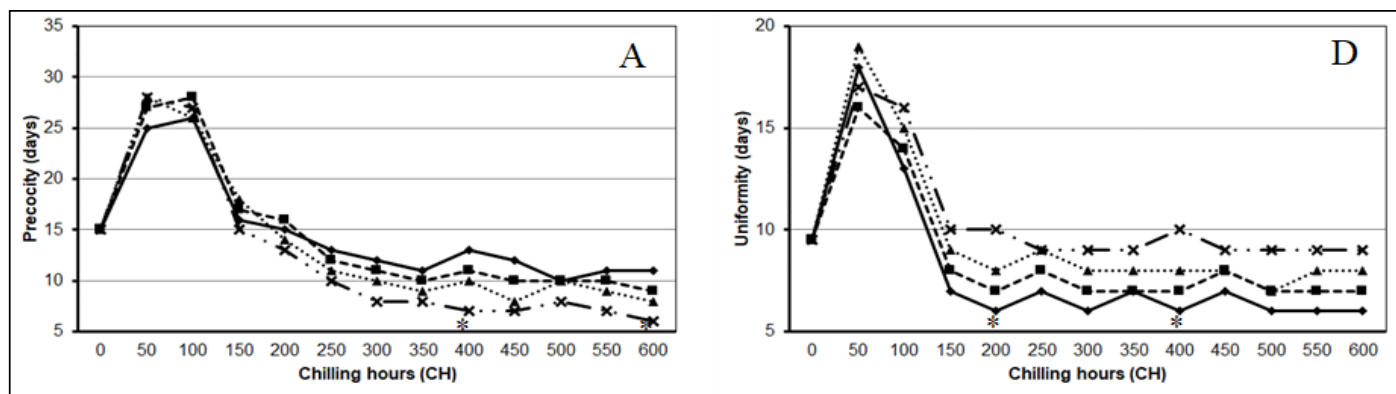

$\rightarrow 7.2^{\circ} \mathrm{C}-\mathbf{- m}-18 / 6 \mathrm{~h}\left(7.2 / 18^{\circ} \mathrm{C}\right) \cdots \mathbf{A} \cdot \cdot 12 / 12 \mathrm{~h}\left(7.2 / 18^{\circ} \mathrm{C}\right) \rightarrow 6 / 18 \mathrm{~h}\left(7.2 / 18^{\circ} \mathrm{C}\right)$
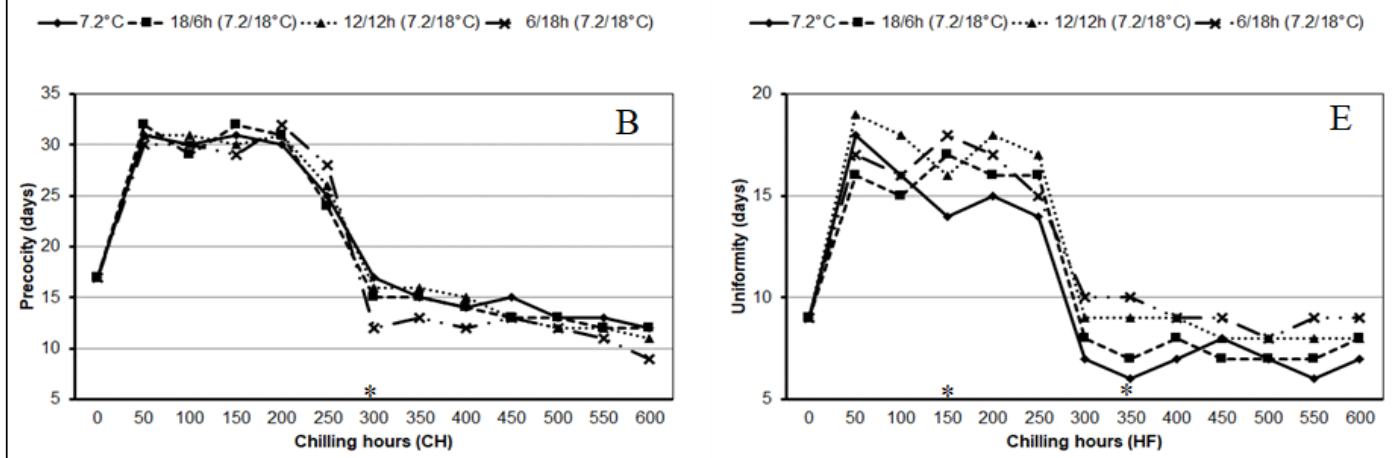

$\rightarrow 7.2^{\circ} \mathrm{C}-\boldsymbol{*}-18 / 6 \mathrm{~h}\left(7.2 / 18^{\circ} \mathrm{C}\right) \cdots \cdot \cdots 12 / 12 \mathrm{~h}\left(7.2 / 18^{\circ} \mathrm{C}\right) \rightarrow \boldsymbol{*} \cdot 6 / 18 \mathrm{~h}\left(7.2 / 18^{\circ} \mathrm{C}\right)$
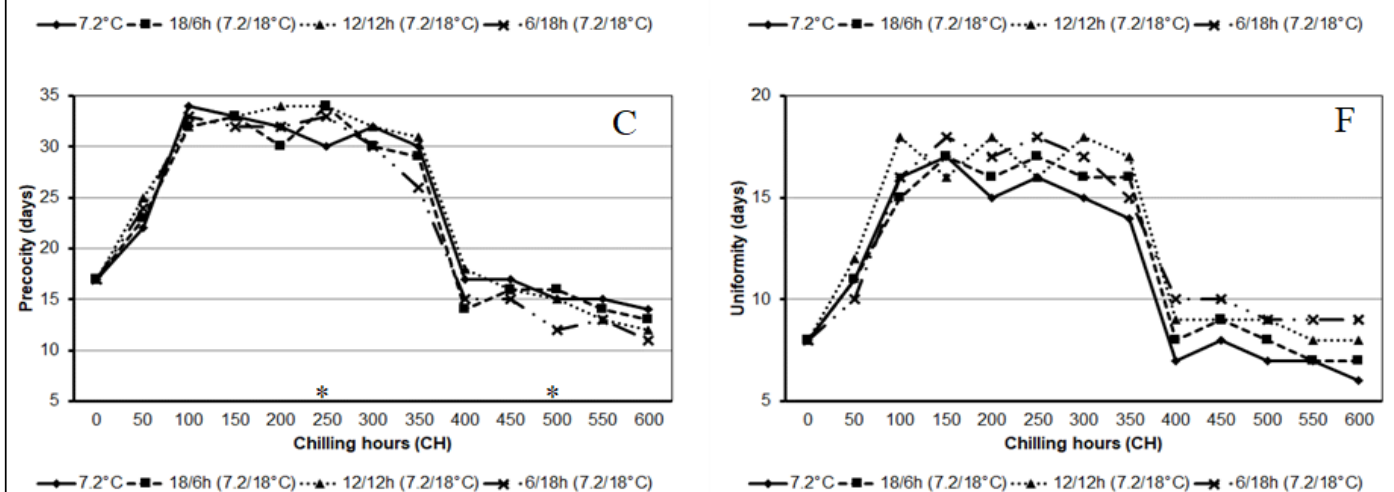

Figure 3 - Precocity and uniformity of budburst of 'Chardonnay' (A, D), 'Merlot' (B, E) and 'Cabernet Sauvignon' (C, F) subjected to a constant temperature of $7.2{ }^{\circ} \mathrm{C}$ and alternating temperatures of $7.2 / 18{ }^{\circ} \mathrm{C}$ during the dormancy period. Significant differences in budding precocity and uniformity within each chilling hour by the Tukey's test $(\mathrm{P}<0.05)$ are marked with an $\left(^{*}\right)$.

number of days to reach the budburst remained high, decreasing as the numbness was overcome (Figures $3 \mathrm{~A}, 3 \mathrm{~B}$ and $3 \mathrm{C}$ ), a trend that was also observed by LEITE et al. (2006) in peach, ALVAREZ et al. (2018) in grapevine, and NAOR et al. (2003) in apple trees. In case of uniformity, the budburst showed to be uneven during induction and full endodormancy, being synchronized after the latency period was over (Figures 3D, 3E and 3F). CAMPOY et al. (2011) and MARAFON et al. (2011) also reported a positive effect of low temperatures on the uniformity of budding of apricot and pear buds, during dormancy.
However, LUEDELING \& BROWN (2011) stated that information on precocity and uniformity are not currently considered in budburst prediction models and should be included in future models to increase their effectiveness and applicability.

\section{CONCLUSION}

Chilling requirements to overcome endodormancy differ among grapevine cultivars, with 'Chardonnay', 'Merlot' and 'Cabernet Sauvignon' having total requirements of 150,300 and $400 \mathrm{CH}$,

Ciência Rural, v.51, n.11, 2021. 
respectively. Daily cycles that alternate low (7.2 ${ }^{\circ} \mathrm{C}$ ) and mild $\left(18{ }^{\circ} \mathrm{C}\right)$ temperatures do not interfered with the evolution process of endodormancy in Vitis vinifera vines. Budburst precocity and uniformity are higher after meeting the chilling requirement of each genotype during dormancy.

\section{ACKNOWLEDGMENTS}

The authors would like to thank Conselho Nacional de Desenvolvimento Científico e Tecnológico ( $\mathrm{CNPq})$ for the financial support (project 424389/2018-5). This study was financed in part by the Coordenação de Aperfeiçoamento de Pessoal de Nível Superior (CAPES), Brasil - Finance code 001.

\section{DECLARATION OF CONFLICT OF INTEREST}

The authors declare no conflict of interest. The founding sponsors had neither any role in the design of the study, nor in the collection, analysis, or interpretation of data, in the writing of the manuscript, and the decision to publish the results.

\section{AUTHORS' CONTRIBUTIONS}

Rafael Anzanello conceived and designed the experiments. All authors installed, conducted and collected data from the experiments. Rafael Anzanello performed statistical analysis of experimental data. All authors prepared the draft of the manuscript, critically revised and approved of the final version.

\section{REFERENCES}

ALVAREZ, H. C et al. Time-to-event analysis to evaluate dormancy status of single-bud cuttings: an example for grapevines. Plant Methods, v.94, n.14, p.1-13, 2018. Available from: <https:// plantmethods.biomedcentral.com/track/pdf/10.1186/s13007-0180361-0>. Accessed: Aug. 30, 2020. doi: 10.1186/s13007-0180361-0.

ANZANELLO, R. et al. Bud dormancy in apple trees after thermal fluctuations. Pesquisa Agropecuária Brasileira, v.49, n.6, p.457-464, 2014. Available from: <http:/www.scielo.br/pdf/ pab/v49n6/0100-204X-pab-49-06-00457.pdf > . Accessed: Aug. 06, 2020. doi: 10.1590/S0100-204X2014000600007.

ANZANELLO, R. et al. Chilling requirements and dormancy evolution in grapevine buds. Ciência e Agrotecnologia, v.42, n.4, p.364-371, 2018. Available from: $<$ http://www.scielo.br/pdf/cagro/ v42n4/1981-1829-cagro-42-04-364.pdf $>$. Accessed: Aug. 22, 2020. doi: 10.1590/1413-70542018424014618.

CARDOSO, L. S. et al. Climate availability for apple trees in Vacaria, southern Brazil. Ciência Rural, v. 42, n. 11, p.1960-1967, 2012. Available from: $<$ https://www.alice.cnptia.embrapa.br/alice/ bitstream/doc/941771/1/CARDODOCiRuralv42n11p19602012. pdf $>$ Accessed: Aug. 10, 2020. doi: 10.1590/S010384782012005000097

CAMPOY, J. A. et al. High temperatures and time to budbreak in low chill apricot 'Palsteyn'. Towards a better understanding of chill and heat requirements fulfillment. Scientia Horticulturae, v.129, n.4, p.649-655, 2011. Available from: $<$ https://www.sciencedirect. com/science/article/pii/S0304423811002421>. Accessed: Aug. 12, 2020. doi: 10.1016/j.scienta.2011.05.008.

COOKE, J. E. K. et al. The dynamic nature of bud dormancy in trees: environmental control and molecular mechanisms. Pant, Cell and Environmet, v.35, n.10, p.1707-1728, 2012. Available from: $<$ https://www.ncbi.nlm.nih.gov/pubmed/22670814>. Accessed: Aug. 06, 2020. doi: 10.1111/j.1365-3040.2012.02552.x.

DOKOOZLIAN, N. K. Chilling temperature and duration interact on the budbreak of 'Perlette' grapevine cuttings. HortScience, v.34, n.6, p.1054-1056, 1999. Available from: <https://journals. ashs.org/hortsci/view/journals/hortsci/34/6/article-p1.xml>. Accessed: Aug. 06, 2020. doi: 10.21273/HORTSCI.34.6.1.

EREZ, A. et al. Quantitative chilling enhancement and negation in peach buds by high temperatures in a daily cycle. Journal of the American Society for Horticultural Science, v.104, n.4, p.536$540,1979$.

EREZ, A; FISHMAN, S. The Dynamic Model for rest completion in peach buds. Acta Horticulturae, n.276, p.165-174, 1990.

FELIPPETO, J. et al. Modelos de previsão de brotação para a cultivar de videira Cabernet Sauvignon na Serra Gaúcha. Agropecuária Catarinense, v. 26, n. 1, p. 85-91, 2013.

FERGUSON, J. C. et al. Dynamic thermal time model of cold hardiness for dormant grapevine buds. Annals of Botany, v.107, n.3, p.389-396, 2011. Available from: $<$ https://www.researchgate. net/publication/49734370>. Accessed: Aug. 06, 2020. doi:10.1093/ $\mathrm{aob} / \mathrm{mcq} 263$.

GUERRIERO, R. et al. The effect of cyclic and constant temperatures in fulfilling the chilling requirements of two apricot cultivars. Acta Horticulturae, 192:41-48, 1985.

LEITE, G. B. et al. Physiological and biochemical evolution of peach leaf buds during dormancy course under two contrasted temperature patterns. International Journal of Horticultural Science, v.12, n.4, p.15-19, 2006. Available from: <https://www.researchgate.net/ publication/281471660>. Accessed: Aug. 03, 2020.

LUEDELING, E.; BROWN, P.H. A global analysis of the comparability of winter chill models for fruit and nut trees. International Journal of Biometeorology, v.55, n3, p.411421, 2011. Available from: <https://www.researchgate.net/ publication/45801031>. Accessed: Aug. 03, 2020. doi: 10.1007/ s00484-010-0352-y.

MANDELLI, F. et al. Fenologia da videira da na Serra Gaúcha. Pesquisa Agropecuária Gaúcha, v.9, n.1-2, p.129144, 2003. Available from: <http://www.fepagro.rs.gov.br/ upload/1398800267_art15.pdf>. Accessed: Aug. 14, 2020.

MARAFON, A. C. et al. Chilling privation during dormancy period and carbohydrate mobilization in Japanese pear trees. Scientia Agricola, v.68, n.4, p.462-468, 2011. Available from: <http:// www.scielo.br/pdf/sa/v68n4/v68n4a11.pdf>. Accessed: Aug. 14, 2020. doi: 10.1590/S0103-90162011000400011.

MELKE, A. The physiology of chilling temperature requirements for dormancy release and bud-break in temperate fruit trees grown at mild winter tropical climate. Journal of Plant Studies, v.4, n.2, 
p.110-156, 2015. Available from: <https://www.researchgate.net/ publication/282423160>. Accessed: Aug. 05, 2020. doi: 10.5539/ jps.v4n2p110.

NAOR, A. et al. Temperature effects on dormancy completion of vegetative buds in apple. Journal of the American Society for Horticultural Science, v.128, n.5, p.636-641, 2003. Available from: <https://journals.ashs.org/jashs/view/journals/jashs/128/5/ article-p636.pdf $>$. Accessed: Aug. 10, 2020.

RICHARDSON, E. A. et al. A model for estimating the completion of rest for 'Redhaven' and 'Elberta' peach trees. HortScience, v.9, n.4, p.331-332, 1974
SHALTOUT, A. D; UNRATH, C. R. Rest completion prediction model for 'Starkrimson Delicious' apples. Journal of the American Society for Horticultural Science, v.108, n.6, p.957-961, 1983.

SUGIURA, T. et al. The relationship between temperature and effect on endodormancy completion in the flower bud of 'Hakuho' peach. Journal of Agricultural Meteorology, v.66, n.3, p.173179, 2010. Available from: <https://www.jstage.jst.go.jp/article/ agrmet/66/3/66_66.3.4/_pdf/-char/en>. Accessed: Aug. 14, 2020.

WEINBERGER, J.H. Chilling requirements of peach varieties. Proceedings of the American Society for Horticultural Science, v.56, p.122-128, 1950. 